\title{
REFLECTION
}

\section{'Be Gentle and Be Sincere About It': A Story About Community-Based Primary Care Research}

\author{
Andrew L. Sussman, PbD, MCRP \\ Marino Rivera ${ }^{2}$ \\ 'Department of Family and Community \\ Medicine, University of New Mexico \\ Health Sciences Center, Albuquerque \\ ${ }^{2}$ RIOS Net Community Advisory Board \\ Albuquerque, New Mexico
}

\begin{abstract}
Practice-based researchers in primry care have increasingly recognized the need to include community members in research efforts. In this reflective vignette, the importance of community engagement is realized through the researcher's ability to elicit and interpret an alternative story told by a respected local resident in a focus group. The focus group was part of a study examining communication between patients and clinicians about traditional medicine in New Mexico. During this session, yerba mansa, a plant used in traditional medicine, became a powerful cultural metaphor for expressing concerns about the intentions of outside researchers. This story shows how creating opportunities for sustained engagement with the people we serve can lead to more sensitive ways to establish research partnerships.
\end{abstract}

Ann Fam Med 2008:6:463-465. DOI: 10.1370/afm.891.

I was late March and piles of snow in the clinic parking lot reminded us that winter in northern New Mexico held on longer in these small mountain villages. A colleague and I had set off early in the morning to this remote Hispanic community to conduct a focus group with practice staff and community members as the first step in a study examining how patients and clinicians communicate about traditional, complementary, and alternative medicine use. Nestled in the foothills of the Sangre de Cristo Mountains, the village traces its history back to the early 1600s, when Spanish explorers first settled in these lush river valleys. As a link to the past, small family farms and ranches still provide a way of living for most residents.

A contact at the clinic recruited participants by explaining that our aim was to learn more about how local residents use and discuss traditional medicine with their primary care clinicians. This session was an opportunity to gather community input as a way to help refine interview guides to be used in the study. Based on our experience in conducting research among historically marginalized communities across New Mexico, however, we also knew that gaining the trust of these community members was an equally, if not more, important outcome.

Our contact led us to the rear of the clinic and into a small conference room. We unpacked our gear, placing the audio recorder in the center of the old wooden table, and neatly stacked the consent forms for distribution. Our participants began to arrive, and we made small talk until all 6 had settled in their seats. My colleague and I introduced ourselves, explained the purpose of the focus group, and asked each person to share his or her name and role in the community or clinic. Five of the 6 participants were female, and all had spent most of their lives in the community. 
With formalities out of the way, I was eager to hear from the group and hit "record."

Within about 10 minutes, I was already worried about the session. Marcos (a pseudonym), the lone male participant, had already begun to take over the discussion. Likely in his early 60s, Marcos had a commanding presence and the smooth cadence of an experienced story teller. A lifelong resident of this small northern New Mexico village, his stories were rich in historical context and depth. As the group moderator, I was initially grateful for such a thoughtful and articulate participant. Marcos, however, had already turned an introductory question about things that are important to people in the community into a history lesson on how ways of life throughout the region have changed. I was growing increasingly concerned about being able to complete the set of questions and the fading involvement of the other 5 participants.

I reached deeply into my bag of moderator tricks to gently redirect the conversation back to the group: "OK, let's hear from some other folks...." Nothing worked. After about 20 minutes of the planned hourlong session, I felt we had reached a fork in the road. I could either make a final stand at trying to equalize input from the group-and possibly risk offending Marcos and the other participants-or just loosen the reins and risk not getting answers to the questions we had come to ask. I decided to listen to my instincts and, in turn, to Marcos. He was wrapping up a long response to the role of traditional herbs in the community and said the following:

The practice of the herbs was not an isolated practice-it was a very strong integral part of a system. Scientists have a problem understanding this, researchers have a problem understanding this, and I have to say it, and I'm going to say it this way: if you take the part away from the whole, you're taking a part away from the whole for another motive, and the motive is usually to exploit it. If you don't look at it as an integral part of a lifestyle of the people, you're gonna miss it and we're gonna end up with a beautiful glowing report that's gonna be false.

Marcos spoke these words with an unmistakable intensity, and for the first time during the session I sensed that his comments were directed at me. Stealing a quick glance at the other participants, I noticed they too were hanging on every word. As I digested the meaning of this statement, the decision to let go became clear. I sat back, loosened my grip on the interview guide, and encouraged him to tell us more.

Perhaps sensing that the group was now in his hands, an animated Marcos launched into a story about his parents, now deceased, and their roles in the community. He had been clearing out some of their old belongings a few weeks before the focus group and came across an herb he identified as yerba mansa.* Another participant asked him to say more about it, and he responded: "The translation means to be 'gentle and kind.' So, it's the herb that you take to calm you, because it's for the heart. You have to be kind and gentle because it's for the heart. Even the name tells you that."

As my role shifted away from moderating the group, the other participants actually became more involved. The atmosphere felt more relaxed and insider jokes and nods of acknowledgment marked the remainder of the conversation. With Marcos clearly at the helm, the focus group had become more of a social gathering, and previously silent participants began to share their stories and even teased Marcos about "getting off his soapbox." As the end of the session grew near, I thanked everyone for sharing their stories and asked if there were any other comments before wrapping up. Not surprisingly, Marcos, who was sitting next to me, leaned in to get the last word. As he began talking, I noticed that he reached a hand in to his shirt pocket and pulled out what appeared to be a dried root, caked with dirt. Extending his hand, he identified the object as yerba mansa, and motioned for me to take the offering. As he dropped it in my hand, he concluded the session by saying, "So remember the name of that herb, $\mathrm{OK}$ ? It means to be tame and tameness comes in the form of gentleness and kindness. Be gentle and kind, but most of all, be sincere about it."

An increasingly important part of practice-based research is the recognition that our efforts to improve health must include the voices of community stakeholders. This involvement has both practical and ethical implications. In terms of the former, conducting formative work with community members can help us better understand how to design our studies in ways that fit better with local needs. The latter relates to the shared experience, especially among historically underrepresented groups, that research has been more exploitive than beneficial. As I reflected on these events, it became clear to me that I had come perilously close to misinterpreting the real focus of the focus group: me. The session was ultimately an opportunity for community residents to evaluate my intentions and, in the process, protect themselves against an outside researcher potentially seeking to learn about traditional medicine for uncertain ends.

As a medical anthropologist with RIOS Net, a prac-

\footnotetext{
* Yerba mansa (Anemopsis californica) is a member of the Saururaceae family and is native to the Southwestern United States and Mexico. The active compound in yerba mansa is methyleugenol, an antispasmodic, and it has been used medicinally to treat inflammation of the mucous membranes, arthritis, and other inflammatory diseases. The herb can be taken orally as a tea, tincture, infusion, or dried in capsule form. Yerba is Spanish for "herb" and mansa is the feminine form of the Spanish word "manso" meaning "tame, tranquil or calm." For additional information, see Moore M. Medicinal Plants of the Desert and Canyon West. Santa Fe, NM: Museum of New Mexico Press; 1989.
} 
tice-based research network in New Mexico serving primarily Hispanic and Native American populations, I understand that our efforts to conduct research with these groups come with baggage. Every contact with community members is part of a process of continually building and sustaining good relationships. Given the fragile nature of these ties, it has been vitally important in our network operations to initiate and sustain dialog with members of these groups. This close collaboration enables them to help shape the direction of our research priorities while adding historical and cultural context that would be otherwise missing.

We are fortunate to have dedicated community members involved in making sure our research is appropriate across New Mexico's diverse settings. The local contact at the clinic who helped recruit participants for this focus group has made the long drive down to Albuquerque for years as a member of our Community Advisory Board. Using both humor and a razor sharp wit, he has relayed the struggles of his community. Through these tales, told over flat soda and soggy sandwiches at our quarterly meetings, he has told the story of a small village trying to sustain its traditions in changing times. As a result, when Marcos spoke about the lack of jobs, low wages, and losing youth to the cities, I recognized this story as one I had heard many times before. On that cold morning in March, as I worried about finishing my interview guide, my decision to defer to Marcos was based on realizing that my role was to listen and convey back to the group that I understood. I believe he waited purposefully until the end of the session to give me the yerba mansa, deciding to offer it only after I gained his trust.

In the weeks after this focus group session, we returned to the clinic to interview patients and clinicians. The piles of snow in the parking had melted and wildflowers were shooting up in fields across from the clinic. Upon my arrival, the nurse manager greeted me by name, offered me some coffee, and helped me get settled. Once I was ready, she escorted me to the wait- ing area and introduced me to each patient, explaining the purpose of our study. Through the brief small talk, I was now able to see that the nurse manager was telling each patient (her neighbors) another story that made all the difference-that I was OK. In turn, every patient approached agreed to participate and, more importantly, generously shared their stories about health and healing with me.

The challenge for primary care clinicians and researchers seeking to connect and work more closely with the communities we serve is to create opportunities for engagement so that we can recognize the stories that affect our work. Our research efforts have clearly benefited from this collaboration, and I am fortunate to have a personal reminder nearby at all times. Amidst the piles on my desk, I keep the piece of yerba mansa that Marcos gave me. Often, as I'm preparing to head out, I glance over at the shriveled herb and am reminded of his words that provide perhaps the simplest and most important guidance to conducting both clinic- and community-based research: be gentle and be sincere about it.

To read or post commentaries in response to this article, see it online at http://www.annfammed.org/cgi/content/full/6/5/463.

Key words: Research, participatory; Anemopsis californica; Hispanic Americans; anthropology, cultural; complementary therapies; practicebased research network

Submitted February 5, 2008; submitted, revised, May 12, 2008; accepted May 15, 2008.

Funding support: This project was supported by grant R21 AT00232301 from the National Center for Complementary and Alternative Medicine.

Acknowledgments: The authors sincerely appreciate the participation and dedication of our community partners. Through their generosity and patience, we are better able to exchange the stories that matter. We also want to thank Brian Shelley, MD; Robert Williams, MD, MPH; Alissa Segal, PharmD; and Benjamin Crabtree, PhD, for sharing their time, experience, and insights. 